\title{
Ocurrence of the chestnut long-tongued bat Lionycteris spurrelli Thomas, 1913 (Chiroptera, Phyllostomidae) in the Northeastern Atlantic Forest, Brazil
}

\author{
Thais de Castro Lira ${ }^{1,3}$, Antonio Rossano Mendes Pontes ${ }^{1} \&$ Katharine Raquel Pereira dos Santos ${ }^{2}$ \\ ${ }^{1}$ Laboratório de Estudo e Conservação da Natureza, \\ Departamento de Zoologia, Centro de Ciências Biológicas - CCB, \\ Universidade Federal de Pernambuco - UFPE, \\ Rua Prof. Moraes Rego, 1235, Cidade Universitária, CEP 50740-620, Recife, PE, Brazil \\ ${ }^{2}$ Núcleo de Biologia, Centro Acadêmico de Vitória, \\ Universidade Federal de Pernambuco - UFPE, \\ Rua do Alto do Reservatório, s/n, Bela Vista, CEP 55608-680, \\ Vitória de Santo Antão, PE, Brazil, www.ufpe.br \\ ${ }^{3}$ Corresponding author: Thais de Castro Lira, e-mail: thaisclira@gmail.com,www.ufpe.br/zoologia
}

LIRA, T.C., MENDES PONTES, A.R. \& SANTOS, K.R.P. Ocurrence of the chestnut long-tongued bat Lionycteris spurrelli Thomas, 1913 (Chiroptera, Phyllostomidae) in the Northeastern Atlantic Forest, Brazil. Biota Neotrop. 9(1): http://www.biotaneotropica.org.br/v9n1/en/abstract?short-communication+bn00909012009.

Abstract: During an inventory fieldwork carried out at Usina Salgado property in the county of Ipojuca, Pernambuco, Brazil, we captured a Lionycteris spurrelli specimen in a forest fragment known as Mata do Mingú ( $8^{\circ} 31^{\prime} 29^{\prime \prime} \mathrm{S}$ and $35^{\circ} 03^{\prime} 26^{\prime \prime} \mathrm{W}$ ). This marks the first occurrence for the northeast region and therefore, the first record for the state of Pernambuco, widening its distribution area within Atlantic Forest. The extension of the occurrence area points out this record as being the oriental limit for the species.

Keywords: Floresta Atlântica, Phyllostomidae, Glossophaginae, range extension, Pernambuco.

LIRA, T.C., MENDES PONTES, A.R. \& SANTOS, K.R.P. Ocorrência do morcego Lionycteris spurrelli Thomas, 1913 (Chiroptera, Phyllostomidae) na Floresta Atlântica do nordeste do Brasil. Biota Neotrop. 9(1): http://www.biotaneotropica.org.br/v9n1/pt/abstract?short-communication+bn00909012009.

Resumo: Durante um trabalho de campo realizado nas propriedades da Usina Salgado, no município de Ipojuca, Pernambuco, foi capturado um indivíduo da espécie Lionycteris spurrelli, no fragmento denominado Mata do Mingú $\left(8^{\circ} 31^{\prime} 29^{\prime}\right.$ 'S e $\left.35^{\circ} 03^{\prime} 26^{\prime \prime} \mathrm{W}\right)$. O fato registra a primeira ocorrência para a região Nordeste e conseqüentemente o primeiro registro para o estado de Pernambuco, ampliando a área de distribuição do morcego na Floresta Atlântica. A extensão da área de ocorrência aponta este registro como o limite oriental para a espécie.

Palavras-chave: Floresta Atlântica, Phyllostomidae, Glossophaginae, ampliação da distribuição, Pernambuco. 


\section{Introduction}

Nectar-feeding bats of family Phyllostomidae had developed a specially modified morphological system, as an elongated rostrum, gaps between teeth or absence of teeth and presence of long tongue, to meet their food habit that is fundamentally liquid, but may eventually include other items like pollen or insects (Freeman 1995, Solmsen 1998, Carstens et al. 2002).

There are controversies among distinct authors regarding the number of genera and species and their relationships (Griffiths 1982, Koopman 1993, Wetterer et al. 2000, Baker 2003, Gregorin \& Ditchfield 2005, Woodman \& Timm 2006, Woodman 2007). However, there is some agreement that the subfamily Glossophaginae has 16 genera distributed in three distinct tribes, namely: Phyllonicterines: Phyllonycteris and Erophylla; Glossophagines: Anoura, Choeroniscus, Choeronycteris, Glossophaga, Hylonycteris, Leptonycteris, Lichonycteris, Monophyllus, Musonycteris, and Scleronycteris; Lonchophyllines: Lonchophylla, Platalina, Lionycteris and Xeronycteris.

Accordingly to Simmons (2005), there are eight genera and a total sum of 14 species for Brazil, namely: tribe Glossophagini: Anoura (A. caudifer (E. Geoffroy, 1818) and A. geoffroyi Gray, 1838); Choeroniscus (C. minor Peters, 1868); Glossophaga (G. comissarisi Gardner, 1962, G. longirostrisi Miller, 1898 and G. soricina (Pallas, 1766)); Lichonycteris (L. obscura Thomas, 1895); Scleronycteris (S. ega Thomas, 1912). tribe Lonchophyllini: Lionycteris (L. spurrelli, Thomas, 1913); Lonchophylla (L. bokermanni Sazima, Vizotto and Taddei, 1978, L. dekeyseri Taddei, Vizotto and Sazima, 1983, L. mordax Thomas, 1903 and L. thomasi J. A. Allen, 1904) (Simmons 2005); Xeronycteris (X. vieirai Gregorin and Ditchfield, 2005).

Lionycteris spurrelli occurs from East of Panama, Colombia, Venezuela, Guyana, to Amazonian Peru and Brazil (Eisenberg \& Redford 1999, Simmons 2005; Reis et al. 2007). Following Griffiths and Gardner (2007), the occurrence of L. spurrelli in Brazil has been registered in the Amazonia, in the states of Amazonas (Sampaio et al. 2003), Pará, Amapá (Taddei et al. 1978), and Tocantins (Nunes et al. 2005); Cerrado: in Bahia (Gregorin \& Mendes, 1999), Goiás (Coimbra et al. 1982); and transitional areas of Caatinga/Cerrado: in Minas Gerais (Trajano \& Gimenez, 1998). Furthermore, there are two recent records that have not been mentioned by Griffiths and Gardner (2007), one for the Cerrado biome, in Mato Grosso do Sul (Bordignon, 2006) and one for the Atlantic Forest, in Espírito Santo (Woodman \& Timm 2006).

The objective of this paper is to furnish the first record of the chestnut long-tongued bat $L$. spurrelli for the northeastern Brazil, in state of Pernambuco, and to present a reappraisal on its geographical distribution.

\section{Material and Methods}

Bats were captured with mist-nets monthly for three consecutive nights during six months (from November 2005 to April 2006). Sampling effort was calculated according to Straube \& Bianconi (2002), and totaled $8100 \mathrm{~m}^{2} / \mathrm{h}$. Individuals were processed following Simmons \& Voss (1990) and the guidelines of the American Society of Mammalogists in Gannon et al. (2007). The identification followed Sanborn (1943), Vizotto \& Taddei (1973), Koopman (1994) and Gregorin \& Ditchfield (2005). This research was carried out under IBAMA's federal license No. 05/2006.

\section{Results and Discussion}

During field research in the premises of the Usina Salgado, municipality of Ipojuca, in Pernambuco State, one single individual of Lionycteris spurrelli, an adult female, was captured on December 14, 2005. The specimen was collected in an Atlantic Forest fragment named Mata do Mingú ( $8^{\circ} 31^{\prime} 29^{\prime}$ ' S and 35 $03^{\circ} 26^{\prime}$ W), with an area of 13,4 ha and that is connected to other fragment by a swamp of shallow waters and vegetation comprised exclusively by Montrichardia linifera Araceae, and they are totally isolated from other forest fragments by a matrix of sugar-cane plantations. The collected specimen was deposited in the Coleção de Mamíferos da Universidade Federal da Paraíba, under number UFPB 5764.

This record provides a considerable extension of the distribution of L. spurrelli in Brazil (Figure 1), inserting northeastern Brazil in the occurrence area of the species. Moreover, this fact corroborates the expansion of the distribution of this species on the Atlantic Forest, an occurrence that was previously registered by Woodman \& Timm (2006) for southeastern Brazil. This record refers to a single individual that is housed at Los Angeles County Museum (LACM 62878) and was collected in the Santa Teresa, in the State of Espírito

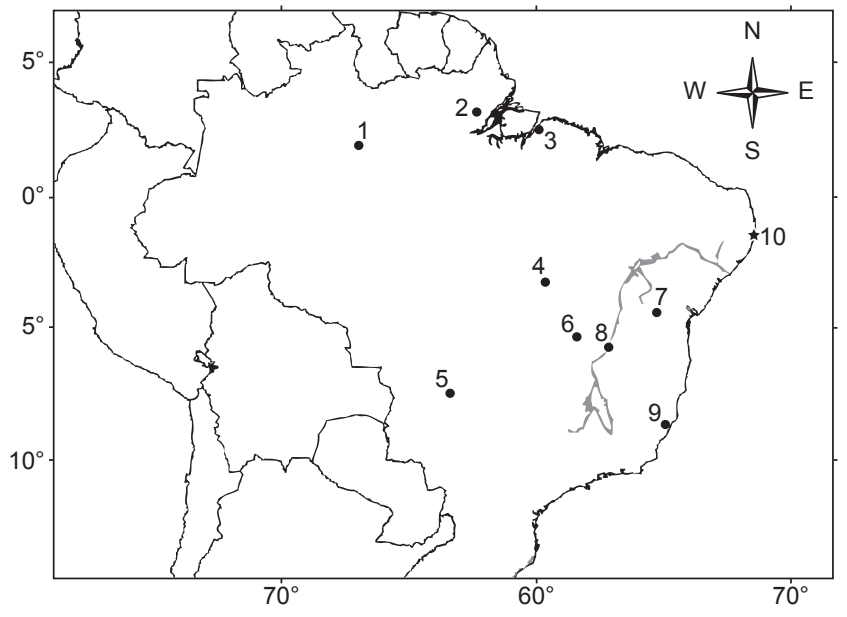

Figure 1. Brazilian distribution of Lionycteris spurrelli, including previous known records (1-9) displayed by dots and the new record (10), represented by a star. 1) Gavião, Amazonas ( $02^{\circ} 27^{\prime} \mathrm{S}$ and $59^{\circ} 47^{\prime} \mathrm{W}$ ); 2) Igarapé Novo, Amapá $\left(00^{\circ} 20^{\prime} \mathrm{S}\right.$ and $\left.52^{\circ} 23^{\prime} \mathrm{W}\right)$; 3 ) Bosque Rodrigues Alves, Pará (01 $27^{\circ} \mathrm{S}$ and $\left.48^{\circ} 29^{\prime} \mathrm{W}\right)$; 4) Aliança do Tocantins, Tocantins ( $11^{\circ} 08^{\prime} \mathrm{S}$ and $\left.48^{\circ} 48^{\prime} \mathrm{W}\right)$; 5) Figueirão, Mato Grosso do $\operatorname{Sul}\left(18^{\circ} 40^{\prime} \mathrm{S}\right.$ and $\left.53^{\circ} 38^{\prime} \mathrm{W}\right)$; 6) Mambaí, Goiás (14 $28^{\prime} \mathrm{S}$ and $\left.46^{\circ} 07^{\prime} \mathrm{W}\right)$; 7) Chapada Diamantina, Bahia (12 $57^{\prime} \mathrm{S}$ and $\left.41^{\circ} 06^{\prime} \mathrm{W}\right)$; 8) Olhos D'água Cave, Minas Gerais ( $15^{\circ} 07^{\prime} \mathrm{S}$ and $\left.44^{\circ} 10^{\prime} \mathrm{W}\right)$; 9) Santa Teresa, Espírito Santo (19 $56^{\circ} \mathrm{S}$ and $\left.40^{\circ} 34^{\prime} \mathrm{W}\right)$; 10) Ipojuca, Pernambuco ( $8^{\circ} 31^{\prime} \mathrm{S}$ and $\left.35^{\circ} 03^{\prime} \mathrm{W}\right)$. The São Francisco River is shown on the map. *Points 5 and 9 coordinates are not provided in their respective articles; their geographical coordinates were estimated using their names.

Figura 1. Distribuição Brasileira de Lionycteris spurrelli, incluindo os registros anteriores (1-9) mostrados em forma de ponto e o novo registro (10) representado por uma estrela. 1, Gavião, Amazonas $\left(02^{\circ} 27^{\prime} \mathrm{S}\right.$ e $\left.59^{\circ} 47^{\prime} \mathrm{W}\right)$; 2, Igarapé Novo, Amapá $\left(00^{\circ} 20^{\prime} \mathrm{S}\right.$ e $\left.52^{\circ} 23^{\prime} \mathrm{W}\right) ; 3$, Bosque Rodrigues Alves, Pará $\left(01^{\circ} 27^{\prime} \mathrm{S}\right.$ e $\left.48^{\circ} 29^{\prime} \mathrm{W}\right)$; 4, Aliança do Tocantins, Tocantins $\left(11^{\circ} 08^{\prime} \mathrm{S}, 48^{\circ} 48^{\prime} \mathrm{W}\right)$; 5, Figueirão, Mato Grosso do Sul (18 $48^{\circ} \mathrm{S}$ e $53^{\circ} 38^{\prime} \mathrm{W}$ ); 6, Mambaí, Goiás ( $14^{\circ} 28^{\prime} \mathrm{S}$ e $\left.46^{\circ} 07^{\prime} \mathrm{W}\right)$; 7, Chapada Diamantina, Bahia (12 $57^{\prime} \mathrm{S}$ e $\left.41^{\circ} 06^{\prime} \mathrm{W}\right)$; 8 , Olhos D'água Cave, Minas Gerais $\left(15^{\circ} 07^{\prime} \mathrm{S}\right.$ e $\left.44^{\circ} 10^{\prime} \mathrm{W}\right)$; 9 , Santa Teresa, Espírito Santo (19 $56^{\prime} \mathrm{S}$ e $\left.40^{\circ} 34^{\prime} \mathrm{W}\right) ; 10$, Ipojuca, Pernambuco ( $8^{\circ} 31^{\prime} \mathrm{S}$ e $\left.35^{\circ} 03^{\prime} \mathrm{W}\right)$. O Rio São Francisco é mostrado no mapa. *As coordenadas dos pontos 5 e 9 não foram fornecidas em seus respectivos artigos. Elas foram estimadas usando os nomes dos seus locais. 
Santo. Despite the fact that no other information of the analyzed individual besides its location and collection identification number is provided by Woodman \& Timm (2006), we consider this record as valid for the Atlantic Forest, since L. spurelli is rarely mistaken with other lonchophylline bats (Griffiths \& Gardner, 2007). The new L. spurrelli record furnished here substantially extends the occurrence approximately $850.8 \mathrm{~km}$ northeastwards, making this specimen from Ipojuca the most oriental record for the species. Moreover, both Bordignon (2006) and Woodman \& Timm (2006) records extend the distribution area nearly $660 \mathrm{~km}$ towards south. This suggests that although this species is rarely captured, it has a wide occurrence area, as opposed to what was previously published (Fonseca et al. 1996), that there were only records for the Amazonian Forest.

Inventories of bat communities from Atlantic Forest in the state of Pernambuco are still scarce. Therefore, this study contributes in the expansion of the geographic distribution knowledge on L. spurrelli, information that was not available in the latest compilation about the Lonchophyllinae subfamily (Griffiths \& Gardner, 2007).

\section{Acknowledgements}

We would like to express our gratitude to the owners of Usina Salgado and the person in charge of the environmental division, Marcel Franz, for making this work possible. We specially thank Alexandre Percequillo and two other anonymous reviewers which contributed with suggestions that were indispensable in the publication of this paper. Thanks to Cibele Caio and Cláudio Magalhães for helping in the field and Ana Paloma, Elis Damasceno and Edgar Silveira for discussions that improved this paper.

\section{References}

BAKER, R.J., HOOFER, S.R., PORTER, C.A. \& VAN DEN BRUSSCHE, R.A. 2003. Diversification among new world leaf-nosed bats: an evolutionary hypothesis and classification inferred from digenomic congruence of DNA sequence. Occas. Pap. Mus. 230(1):1-32.

BORDIGNON, M.O. 2006. Diversidade de morcegos (Mammalia, Chiroptera) do complexo Aporé-Sucuriú, Mato Grosso do Sul, Brasil. Rev. Brasil. Zool. 23(4):1002-1009.

CARSTENS, B.C., LUNDRIGAN, B.L. \& MYERS, P.A. 2002. Phylogeny of the neotropical nectar-feeding bats (Chiroptera:Phyllostomidae) based on morphological and molecular data. J. Mammal. Evol. 9(1-2):23-53.

COIMBRA Jr., C.A.E., BORGES, M.M., GUERRA, D.Q. \& MELO, D.Q. 1982. Contribuição a zoogeografia e ecologia de morcegos em região de Cerrado do Brasil central. Bo. Téc. Rev. Brasil Florestal, 7:34-38.

EISENBERG, J.F. \& REDFORD, K.H. 1999. Mammals of the neotropics: the central neotropics: Ecuador, Peru, Bolivia, Brazil. University of Chicago Press, Chicago.

FREEMAN, P.W. 1995. Nectarivorous feeding mechanisms in bats. Biol. J. Linn. Soc. 56(3):439-463.

FONSECA, G.A.B., HERRMANN, G., LEITE, Y.L.R, MITTERMEIER, R.A., RYLANDS, A.B. \& PATTON, J.L. 1996. Lista anotada dos mamíferos do Brasil. Occas. Pap. Cons. Biol. 4(3):1-38

GANNON, W.L. \& SIKES, R.S. 2007. Guidelines of the American Society of Mammalogists for the use of wild mammals in research. J. Mammal. 88(3):809-823.

GREGORIN, R. \& DITCHFIELD, A.D. 2005. A new gwnus and species of lonchophyllini nectar-feeding bat (Phyllostomidae: Glossophaginae) from northeastern Brazil. J. Mammal. 86(2):403-414.

GREGORIN, R. \& MENDES, L.F. 1999. Sobre quirópteros (Emballonuridae, Phyllostomidae, Natalidae) de duas cavernas da Chapada Diamantina, Bahia, Brasil. Iheringia. Ser. Zool. (86):121-124.

GRIFFITHS, T.A. \& GARDNER, A.L. 2007. Subfamily Lonchophyllinae. In Mammals of South America: marsupials, xenarthrans, shrews, and bats (A.L. Gardner, ed.). University of Chicago Press, Chicago; London, p. 244-255.

GRIFFITHS, T.A. 1982. Systematics of the new world nectar-feeding bats (Mammalia, Phyllostomidae) based on the morphology of the hyoid and lingual regions. Am. Mus. Novit. (2742):1-45.

KOOPMAN, K.F. 1993. Order Chiroptera. In Mammal species of the world: a taxonomic and geographic reference (D.E. Wilson \& D.M. Reeder, eds.). Smithsonian Institution Press, Washington, p. 137-242.

KOOPMAN, K.F. 1994. Chiroptera: systematics. In Handbook of zoology: a natural history of the phyla of the animal kingdom (M. Fisher, ed.). Walter de Gruyter \& Co, New York, p. 1-217.

NUNES,A., MARQUES-AGUIAR, S., SALDANHA, N., SILVA E SILVA, R. \& BEZERRA, A. 2005. New records on the geographic distribution of bat species in the brazilian Amazonia. Mammalia 69(1):109-115.

REIS, N.R., PERACCHI, A.L., PEDRO, W.A. \& LIMA, I.P. 2007. Morcegos do Brasil. Universidade Estadual de Londrina, Londrina.

SAMPAIO, E.M., KALKO, E.K.V., BERNARD, E., RODRÍGUEZHERRERA, B. \& HANDLEY Jr., C.O.A. 2003. A biodiversity assessment of bats (Chiroptera) in a tropical lowland rainforest of central Amazonia, including methodological and conservation considerations. Stud. Neotrop. Fauna E. 38(1):17-31.

SANBORN, C.C. 1943. External characters of the bats of the subfamily. Glossophaginae, 25(24):271-277.

SIMMONS, N.B. 2005. Order chiroptera. In Mammal species of the world: a taxonomic and geographic reference (D.E. Wilson \& D.M. Reeder, eds.). Smithsonian Institution Press, Washington, p. 312-529.

SIMMONS, N.B. \& VOSS, R.S. 1990. Collection, preparation, and fixation of specimens and tissues. In Ecological and behavioral methods for the study of bats (T. H. Kunz \& S. Parsons, eds.). Johns Hopkins University Press, Washington, 533p.

SOLMSEN, E.H. 1998. New world nectar-feeding bats: viology, morphology and craniometric approach to systematics. Bonn. Zool. Monog. 44:1-118.

STRAUBE, F.C.C. \& BIANCONI, G.V. 2002. Sobre a grandeza e a unidade utilizada para estimar esforço de captura com utilização de redes-deneblina. Chirop. Neotrop. 8(1-2):50-1152.

TADDEI, V.A., VIZOTTO, L.D. \& SAZIMA, I. 1978. Notas sobre Lionycteris e Lonchophylla nas coleções do museu paraense Emilio Goeldi (Mammalia: Chiroptera: Phyllostomidae). Bol. Mus. Pa. Emilio Goeldi (92):1-14.

TRAJANO, E. \& GIMENEZ, E.A. 1998. Bat community in a cave from eastern Brazil, including a new record of Lionycteris (Phyllostomidae, Glossophaginae). Stud. Neot. Fauna Environ. 33:69-75.

VIZOTTO, L.D. \& TADDEI, V.A. 1973. Chave para a determinação de quirópteros brasileiros. Francal, São José do Rio Preto.

WETTERER, A.L., ROCKMAN, M.V. \& SIMMONS, N.B. 2000. Phylogeny of phyllostomid bats (Mammalia: Chiroptera): data from diverse morphological systems, sex chromosomes, and restriction sites. B. Am. Mus. Nat. Hist. (248):1-200.

WOODMAN, N. 2007. A new species of nectar-feeding bat, genus Lonchophylla, from western Colombia and western Ecuador (Mammalia: Chiroptera: Phyllostomidae). P. Biol. Soc. Wash. 120(3):340-358.

WOODMAN, N. \& TIMM, R.M. 2006. Characters and phylogenetic relationships of néctar-feeding bats, with descriptions of new Lonchophylla from western South America (Mammalia: Chiroptera: Phyllostomidae: Lonchophyllini). P. Biol. Soc. Wash. 119(4):437-476.

Data Received 30/05/08 Revised 20/12/08 Accepted 16/01/09 
